\title{
種々の階層における塑性理論の発展
}

\section{2. 結晶塑性論とその応用}

\section{Recent Advances and Multi-Hierarchical Perspectives in Plasticity Theory}

\section{II : Crystal Plasticity and Its Applications}

by

Key words : Crystal plasticity, Finite element polycrystal model, Plastic anisotropy, Bauschinger effect, Latent hardening, Multiple slip work hardening

\section{1 まえがき}

従来の連続体塑性論は，降伏曲面の存在を前提に塑性 ポテンシャル理論として体系化されてきた。塑性ひずみ 増分の方向は最大塑性仕事の原理加ら降伏曲面に垂直外 向きとして与えられ，その大きさは加工硬化則から決ま る.すなわち降伏曲面の大きさおよび形状変化が分かれ ば, その材料の構成方程式が得られる. このため降伏曲 面を求めるための膨大な実験的・理論的研究がなされた が, 特に次の問題が課題とされてきた。

（1） 異方性材料の降伏条件の定式化

圧延板などの繊維組織による異方性は，プレス加工に おける成形性評価の重要な因子である。このため現在で もなお様々な異方性降伏条件式の提案が続いている. ど のような関数を採用しようと，それに含まれるパラメー タの数が多ければ実験と合わせることは可能であるが, パラメータ決定のための材料試験が困難となる.

(2) 後絸降伏条件の定式化

等方性材料犬゙としてもひずみ履歴によって降伏曲面は 変化する.これはバウシンガー効果とか交差効果など, 加工硬化の応力空間における異方性のためである. 通常 等方硬化と移動硬化の組み合わせで表現することが多い が，このための新たなパラメータを導入すると，上記の 実空間に打ける塑性異方性パラメータとの識別ができ ない。

（3）降伏曲面における角点

塑性座屈荷重の理論予測を実験値に一致させるため に，塑性ひずみ増分方向の応力増分方向依存性を導入す る必要がある。塑性ポテンシャル理論でこれを考慮する には，降伏曲面に角点の存在を仮定しなければならない。 そこで角点を見つけるための困難な実験が重ねられたが， 賛否両方の報告がなされている.

以上降伏条件の精緻化は様々な困難や矛盾に遭遇して きた. 塑性ポテンシャル理論以外の理論も模索されたが
いずれも実験事実を理解する道具とはなり得なかった。 そこで物理的な実験事実に基づく理論として, 多結晶塑 性論に関心が寄せられるようになった。考え方は古くか ら議論されてきたが，近年の計算機の進歩によりようや く現実的な問題に適用されるようになった。

多結晶モデルとは単結晶の性質を基に多結晶集合体の 性質を予知しようとするものであるが，この場合次の二 つの問題が課題である.

（1）各結晶粒内の微視的応力場と, 集合体全体の巨 視的応力場をいかに関連づけるか.

(2) 単結晶の構成方程式をいかに与えるか.

この二つの問題 について, これまでの流れと現在の状 況を展望し，二，三の応用を紹介する。

\section{2 多結晶モデル}

\section{$2 \cdot 1$ これまでの多結晶理論}

塑性変形が各結晶固有のすべり系によって生ずるもの とする。一般に $r$ 番目のすべり系に扔いて，すべり面単 位法線べクトルを $a_{i}^{(r)}$, すべり方向単位べクトルを $b_{i}^{(r)}$, せん断ひずみ増分を $\dot{\gamma}^{(r)}$ とおく．微視的な塑性ひずみ増 分は次のように表わされる。

$$
\dot{\varepsilon}_{i j}^{p}=\sum_{r}^{(r)} \dot{\gamma}^{(r)} \text { where } C_{i j}^{(r)}=\frac{1}{2}\left(a_{i}^{(r)} b_{j}^{(r)}+a_{i}^{(r)} b_{j}^{(r)}\right)
$$

各結晶粒の微視的応力を $\sigma_{i j}$ とおくと, せん断応力 $\tau$ は次式で与えられる。

$$
\tau^{(r)}=C_{i j}^{(r)} \sigma_{i j}
$$

各すべり系の降伏せん断応力を $k^{(r)}$ と打くと, 降伏条件 (Schmid 則) は次式で表わされる.

$$
\begin{array}{rlll}
\tau^{(r)} \dot{\gamma}^{(r)}>0 & \text { for } & & \left|\tau^{(r)}\right|=k^{(r)} \\
\dot{\gamma}^{(r)}=0 & \text { for } & & \left|\tau^{(r)}\right|<k^{(r)}
\end{array}
$$

Taylor ${ }^{1)}$ の等方硬化則，すなわち各すべり系の降伏せ ん断応力 $k^{(r)}$ は全て $k$ に等しいと仮定すると, 塑性仕事 増分は次式で表わされる.

$$
\dot{W}^{p}=\sum_{r} \tau^{(r)} \dot{\gamma}^{(r)}=k \dot{\Gamma} \quad \text { where } \quad \dot{\Gamma}=\sum_{r}\left|\dot{\gamma}^{(r)}\right|
$$


$k$ が塑性仕事の関数であると仮定すると, 同時にそれは せん断ひずみ和 $\Gamma$ の関数でもある。すなおち

$$
k=H(\Gamma)
$$

ただし $H(\Gamma)$ は加工硬化関数である.

Taylor は, 各結晶粒の塑性ひずみは全て巨視的な塑性 ひずみ增分 $\dot{E}_{i j}^{p} に$ 等しいと仮定した。この仮定は全くの 直感からなされたものであるが，第一近似として現在ま

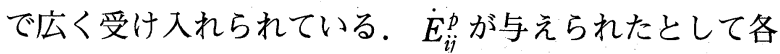
すべり系の $\dot{\gamma}^{(p)}$ をいかに定めるかを考える. 式 (1)より

$$
\sum_{r} C_{i j}^{(r)} \dot{\gamma}^{(p)}=\dot{E}_{i j}^{p}
$$

体積一定の条件があるので，上式は 5 個の独立な条件 を与える．FCC 金属の場合 12 個のすべり系があるので 上式を満たすすべり系の組み合わせはかならず存在する が，それをどう見い出すかが問題である. Taylor は仕事 が最小になるすべりが実現されると考え，次の最小す心゙ りの原理を提案した。

“式 (6) の条件の下で，塑性仕事増分すなわち式 (4)

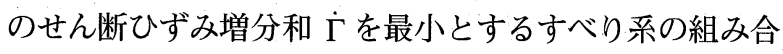
わせが実際に実現する.”

Bishop and Hill ${ }^{2)}$ は単結晶の降伏条件を基に，最小す べりの原理を理論的に導入した，同時に次式で表わされ る最大塑性仕事の原理を証明した。

$$
\left(\sigma_{i j}-\sigma_{i j}^{*}\right) \dot{\varepsilon}_{i j}^{p} \geq 0
$$

これを基に, Taylor のひずみ一定の仮定に理論的根拠を 与えた. Bishop and Hill は FCC 多結晶体の降伏曲面を 理論的に求め, Tresca と Mises の中間の曲面を得た。

負荷の初期とか応力方向が急変する場合, または六方 晶のようにすべり系の少ない金属の場合, 塑性状態の結 晶粒と，弾性状態の結晶粒が共存することになる。この ような問題には次の弾塑性多結晶理論が必要となる。

初めに登場したのが, Eshelby ${ }^{3)}$ の介在物理論を応用し たセルフコンシステントモデルである. 多結晶体の巨視 的応力増分を $\dot{S}_{i j}$ とおくと, 微視的応力場は次式で与え られる。

$$
\dot{\sigma}_{i j}-\dot{S}_{i j}=-2 G(1-\beta)\left(\dot{\varepsilon}_{i j}^{p}-\dot{E}_{i j}^{p}\right)
$$

ただし $\beta=\frac{2(4-5 v)}{15(1-v)} \cdot \overline{\dot{\varepsilon}_{i j}^{p}}=\dot{E}_{i j}^{p}$ とすると上式から $\overline{\sigma_{i j}}=S_{i j}$ が自動的に成立するので, Self-Consistentの条件を満た

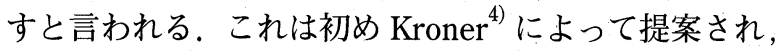
Budiansky and $\mathrm{Wu}^{5)} に よ っ て$ 具体的な計算が行われた ことから通常 KBW モデルと呼ばれている. FCC 非硬化 材単純引張り・単純ねじりの応力ひずみ曲線が計算され, いずれもひずみが大きくなるにつれ応力は一定值に漸近 した.

$$
\sigma_{\max } / 2 k=1.536, \quad \tau_{\max } / k=1.658 .
$$

これは Bishop and Hill の剛塑性理論における降伏応力 の計算結果に完全に一致した.

しかし Hill ${ }^{6}$ は KBW モデルは考えている結晶粒の周 囲の媒質が弾性体の時のみ成立する式であると批判し， 弾性定数の代わりに応力ひずみ曲線の接線係数を用いる モデルを提案した. Hutchinson ${ }^{7)}$ がこれに基づいて FCC
単純引張りの計算 を行った. 図 3 から分かるように流 動 応力は式(9) とくらべかなり低い. Hill モデルは周囲 の媒質全体を一様な塑性負荷状態と仮定しており, 応力 の下限を与えるものと考えられる.

問題は $\mathrm{KBW}$ モデル式 (8) に打いて剛塑性近似 $(G \rightarrow$ の) をすると, $\dot{\varepsilon}_{i j}^{p} \rightarrow \dot{E}_{i j}^{p}$ すなわち Taylor モデルに一致 し, 剛体粒子を含むような問題には適用できないことで ある. そこで複数の結晶粒が同時に塑性変形する多結晶 体の問題を, 改めて Eshelby の変態問題の考元方にした がって解いてみる. 観察点 $x$ を含む結晶粒を $m=0$, 荷 重点 $x^{\prime}$ を含む周囲の結晶粒を $m=1,2,3, \ldots$. と表わすと， 微視的応力場は次式で表わされる.

ただし

$$
\dot{\sigma}_{i j}-\dot{S}_{i j}=-2 G(1-\beta)\left(\dot{\varepsilon}_{i j}^{p}-\dot{E}_{i j}^{p}\right)+\dot{s}_{i j}
$$

$$
\begin{aligned}
& \dot{s}_{i j}(x)=2 G \sum_{m^{\prime}=1}^{\infty}\left(\dot{\varepsilon}_{k l}^{b^{\left(m^{\prime}\right)}}-\dot{E}_{k l}^{p}\right) \int_{a_{m}^{\prime}} \phi_{i j k}\left(x, x^{\prime}\right) n_{l}^{\prime} d A^{\prime} \\
& \phi_{i j k}=\frac{(1-2 v)\left(\delta_{i j} q_{k}-\delta_{k j} q_{i}-\delta_{k i} q_{j}\right)-3 q_{i} q_{j} q_{k}}{8 \pi(1-v) r^{2}} \\
& q_{i}=\left(x_{i}-x_{i}^{\prime}\right) / r, \quad r^{2}=\sum_{i}\left(x_{i}-x_{i}^{\prime}\right)^{2}
\end{aligned}
$$

この式は初め Lin $^{8)}$ が熱応力解析における Duhamel のア ナロジー法を用いて導入し，高橋 ${ }^{9)}$ が Eshelby の考え方 にしたがって再導入したものである.

さて式 (10)で $G \rightarrow \infty$ とするとひずみ偏差 $\Delta \dot{\varepsilon}_{k l}^{p(m)}=$ $\dot{\varepsilon}_{k l}^{p(m)}-\dot{E}_{k l}^{p}$ に関する連立方程式が得られる。もしこの係 数行列が正則であると, ひずみ偏差はすべて 0 となり， やはり Taylor モデルに帰着する。しかし固有値解析を 行ったところ正值半定符号で正則ではないことが分かっ たししがって Lin - 高橋の式は剛体粒子を含む問題に も適用できるが，係数マトリックスに特異性を含むため， 各すべり系のすべりの決定に際し，0/0 の不定形に悩ま されることがある.

\section{$2 \cdot 2$ 有限要素多結晶モデル}

有限要素法 FEM に打ける分割要素を結晶粒一個また は結晶粒群とみなす考えかたを有限要素多結晶モデル FEPM (Finite Element Polycrystal Model) という。こ れによればどのような不均一変形でも結晶粒界における 力と変位の連続を正しく保証することができる. また任 意の境界条件に対応できる。

塑性変形の解析は, 全体の変形過程を何段階かに分割 し, 各変形段階每に FEM を適用する。いま現在の時刻 $t^{1}$ に打ける座標 $x_{i}^{1}$ (または変位 $u_{i}^{1}$ ), 応力 $\sigma_{i j}^{1}$ が分かって いるとして, 次の時刻 $t=t^{1}+\dot{t}$ に扔ける座標 $x_{i}=x_{i}^{1}+\dot{u}_{i}$, 応力 $\sigma_{i j}=\sigma_{i j}^{1}+\dot{\sigma}_{i j}$ を求めるものとする. FEM の定式化に は時刻 $t$ の未知の座標 $x_{i}$ に基づく方法をとることにする. 一つの要素においてひずみ増分文と節点変位増分 $\boldsymbol{u} か ゙$ 次の様にマトリックス表現できるものとする.

$$
\dot{\varepsilon}=B \dot{u}
$$

Almansi ひずみが用いられているために, $\boldsymbol{B}$ マトリック スは変形後の座標 $x_{i}$ で評価されなければならない．しか し不安定問題以外の普通の問題では, 各变形段階の初め 
にB を更新 up-date すれば, 各変形ステップ内では一定 と仮定して十分と思われる.

Hookeの法則をマトリックスで表現する.

$$
\sigma=D\left(\dot{\varepsilon}-\dot{\varepsilon}^{p}\right)+\sigma^{1}
$$

ただし $\sigma^{1}$ は一段階前の応力である.

仮想仕事の原理より次の剛性方程式を得る.

$$
K \dot{u}=F+F^{p}
$$

ただし $\boldsymbol{F}$ は節点力，

$$
K=\int B^{T} D B d v, F^{p}=\int B^{T}\left(D \dot{e}^{p}-\sigma^{1}\right) d V
$$

剛性マトリックス $K$ は形式上弾性と同じものなので, 塑 性ひずみなどによる仮想外力 $F^{p}$ を与えれば弾性解析と 全く同じように取り扱うことができる.

各すべり系のせん断ひずみ増分 $\dot{\gamma}^{(r)}$ を決定する条件は， 式 (3) の降伏条件である. しかしこれには未知量 $\dot{\gamma}^{(r)}$ が陽 には表われていない．特に活動すべり系の組み合わせが 事前に分かっていないので， $\dot{\gamma}^{(r)}$ の決定はかなり困難な 問題と考えられてきた。 ここでは実際の現象を忠実に再 現する方法として，逐次累積法を提案する。

初め負荷増分が一気にかけられたとすると，材料はま ず弾性的に応答するはずである.すなわち活動す心゙り系 のせん断応力は降伏応力を越え, これが駆動力となって 転位が動き始める。結晶粒が一個でも塑性変形すると, 集合体全体の力のバランスが変化し塑性変形を起こした 結晶粒の応力は弛緩する. 一方降伏せん断応力は加工硬 化によって上昇する. 変形抵抗の上昇と負荷応力の減少 がバランスしたところで，そのすべり系の活動がやむ.

以上の現象を数值的に再現するために，全てのすべり 系に対して, 一斉に次の繰り返し計算を適用する.

$$
x_{(i)}^{(r)}=x_{(i-1)}^{(r)}+\left(\zeta^{(r)} \tau^{(r)}-k^{(r)}\right) \Delta \rho /(2 G)
$$

ただし $\zeta^{(r)}=\operatorname{sign}\left(\tau^{(r)}\right), x^{(r)}=\zeta^{(r)} \dot{\gamma}^{(r)}, \Delta \rho$ は繰り返し計算 のステップ幅である. 初期值 $x_{(0)}^{(r)}=0$ とする. 繰り返す度 に仮想外力 $\boldsymbol{F}^{p}$ を更新し剛性方程式を解く。したがって $\tau^{(r)}$ は逐次更新される。ここで次の累積条件を課す。“繰 り返しの途中で $x^{(r)}<0$ が発生したらそのすべり系につい ては $x^{(r)}=0$ とおいて，全体の繰り返し計算を続行する。”

この累積条件は， $x^{(r)}$ が正值あるいは 0 のいずれかに収 束することを保証し，それぞれ活動 active , 非活動 nonactive に対応する. したがって活動か非活動かの判断 を事前に行う必要はなく, 収束の結果としてそれが分か ることになる．実際の計算の経験によれば， $\Delta \rho$ を過大に とると発散するが $\Delta \rho=0.5$ 程度で効率よく収束する.

本解法において各すべり系の降伏せん断応力には何ら 制約がなく，例えばグラフで与えられていてもよい．こ のため多結晶金属の材料試験から，単結晶内の多重すべ りに护加工硬化則を探るツールとして，FEPM を利 用することができる。

\section{$2 \cdot 3$ 数值材料試験}

様々な結晶方位を持つ N ケの立方体結晶粒が 1 ブロッ クを形成し，これと同じブロックが図 1 に示す様に 3 次 元的に無限に積み重ねられた多結晶集合体を考える.

巨視的応力 $S_{i j} \cdot$ ひずみ増分 $\dot{E}_{i j}$ スピン増分 $\dot{\Omega}_{i j}$ はそれぞ

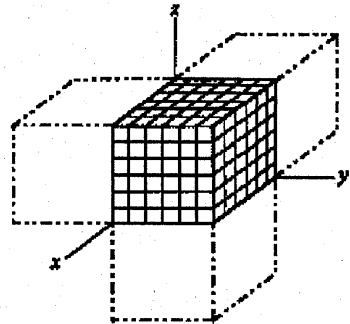

図1多結晶モデル

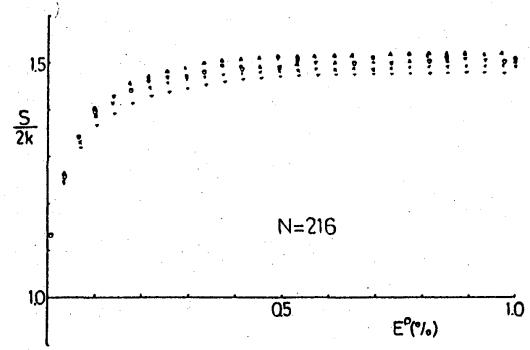

目 2 非硬化 FCC 単純引張り応力ひずみ曲線

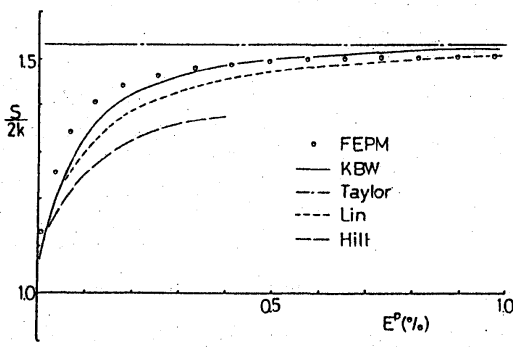

図 3 様々な多結晶モデルの比較

れ微視的応力 $\sigma_{i j}$ ・ひずみ増分 $\dot{\varepsilon}_{i j} \cdot$ スピン増分 $\dot{\omega}_{i j}$ の 1 ブ ロック内の平均として定義する。塑性仕事も同様に定義 されるためには，ブロック境界において余分の仕事が消 費されてはいけない。このため隣接ブロック間で変位が 連続であることが望ましい。そこでブロック表面の境界 条件として，巨視的ひずみを与える一様変位場 $\dot{U}_{i}$ を与え ることにする.

$$
\dot{U}_{i}=\left(\dot{E}_{j i}+\dot{\Omega}_{j i}\right) x_{j}
$$

例題として $z$ 方向の単純引張りを考る. $z$ 方向に変形 が一様として次の条件から巨視的スピンを決定する.

$$
\frac{\partial \dot{U}}{\partial z}=\dot{E}_{z x}+\dot{\Omega}_{z x}=0, \frac{\partial \dot{V}}{\partial z}=\dot{E}_{y z}-\dot{\Omega}_{y z}=0, \dot{\Omega}_{x y}=0 .
$$

時間ステップとして $\dot{E}_{z}=\dot{e}(=0.05 \%)$ を選ぶ. 巨視的応 力のうち $S_{z}$ を除いてすべて 0 とする.

結晶粒数 216 について, 非硬化 FCC 単純引張りの応 力ひずみ関係を図 2 に示す．結晶方位を乱数で与えその ばらつきの様子す．結晶粒数が多くなればばらつきも小 さくなる．図 3 に他の多結晶モデルとの比較をしめす.

\section{3 塑 性 異 方 性}

\section{$3 \cdot 1$ 結晶方位の決定}

等方性材料ならば乱数を用いて結晶方位を一様に与え る. 圧延板のように集合組織を持つ異方性材料の場合は $\mathrm{X}$ 線回折による極点困から結晶方位を決定する。一般に 
は結晶粒方位分布関数 (CODF) を推定する方法が考え られているが，ここではより直接的な方法をのべる．

たとば FCC 金属の場合 (111) 極点図はすべり面密度 を表わしている。そこでステレオ投影の単位球の表面を 等面積に分割し，面積要素毎に $\mathrm{X}$ 線強度の積分值 $\Delta I$ を 求め，これが (111) 面の数に比例していると仮定する. 多結晶モデルの結晶粒の数を $N$ とすると，すべり面の数 は $4 \mathrm{~N}$ であるから， $\Delta I$ の総和が $4 N$ に対応するように各 要素毎の $\Delta I$ を整数化する．アルミニウム圧延板の (111) 極点図を $N=216$ として離散化した例を図 4 に示す.

離散化された $4 N$ 個の極点の任意の一点を一つの結晶 粒のすべり 面方位 $\overrightarrow{a_{1}}$ として採用する. 残りのすべり面 方位 $\overrightarrow{a_{2}} ， \overrightarrow{a_{3}} ， \overrightarrow{a_{4}}$ も極点図のどこかに潜んでいるはずなの で $\overrightarrow{a_{1}}$ のまわりに $\overrightarrow{a_{2}}, \overrightarrow{a_{3}} ， \overrightarrow{a_{4}}$ を回転しこれに最も近い 3 個 の極点の組を探す。これが見つかった所で一個目の結晶 方位が決まる。続いて上で用いられた 4 個の極点を削除 し，残りの極点群から第 2 の結晶方位を定める。このよ うにして $N$ 個の結晶粒の方位を決定する．多結晶モデル の結晶方位から再び極点図を再生した例を図 5 に示す.

\section{$3 \cdot 2$ 圧延板の異方性}

市販のアルミニゥム圧延板（板厚 $2 \mathrm{~mm} ＼mathrm{~ ） の 初 期 圧 延 ~}$ 方向から $0^{\circ}$ 方向, $45^{\circ}$ 方向, $90^{\circ}$ 方向それ乤れに圧下率 $50 \%$ （板厚 $1 \mathrm{~mm}$ まで）の付加圧延を施し，三種類の異方 性板を用意する。この異方性板から様々な方向の引張り 試験片を切り出し，流動応力と $r$ 值を調べる.

一方それぞれの異方性板の極点困から多結晶モデルの 各結晶方位を定め, 様々な方向の数值引張り試験を行な う. 1 ブロックの結晶粒数は 216 , 降伏せん応力は一定と し，のびひずみ $1 \%$ まで計算する．計算に用いた極点図と $r$ 值および流動応力の実験と計算の比較を図 6 に示す.

\section{3・3 格子回転}

変形による塑性異方性の進展を考える，弾性変形によ るひずみとスピンを無視できるとすると，負荷状態にお ける変形 $\left(\dot{\varepsilon}_{i j}, \dot{\omega}_{i j}\right)$ と除荷状態における変形 $\left(\dot{\varepsilon}_{i j}^{p}, \dot{\omega}_{i j}^{p}\right)$ と は，形状は全く同じはずである。しかし方位は食い違う かもしれない。そこで形状をたよりに剛体回転 $\dot{\omega}_{i j}^{r}$ を与 えて両者の方位を一致させたとすると，これは次式で与 えられる。

$$
\dot{\omega}_{i j}^{r}=\dot{\omega}_{i j}-\dot{\omega}_{i j}^{p}
$$

ただし塑性スピン $\dot{\omega}_{i j}^{p}$ は次式で定義される.

$$
\dot{\omega}_{i j}^{p}=\sum_{r} W_{i j}^{(r)} \gamma^{(\dot{r})} \text { where } W_{i j}^{(r)}=\frac{1}{2}\left(a_{i}^{(r)} b_{j}^{(r)}-a_{j}^{(r)} b_{i}^{(r)}\right)
$$

剛体回転だとすると結晶格子も一緒に回転するはずなの

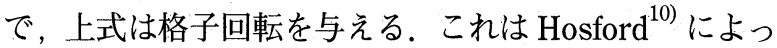

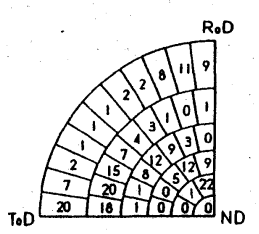

図4 極点図の離散化図

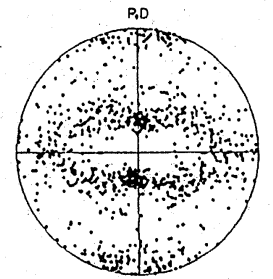

図 5 極点図の再生
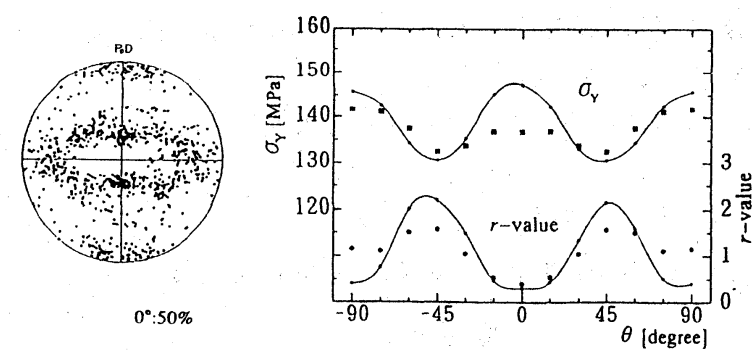

(a) $0^{\circ}$ 方向
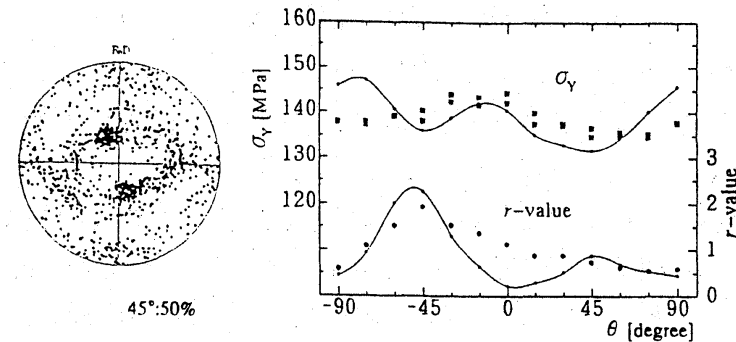

(b) $45^{\circ}$ 方向
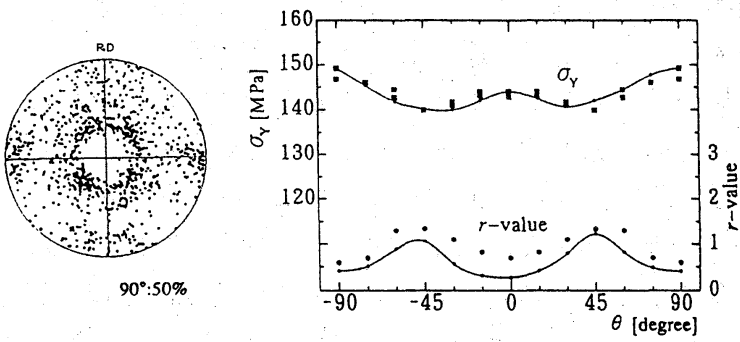

(c) $90^{\circ}$ 方向

図 6 付加圧延されたアルミニウム板の塑性異方性
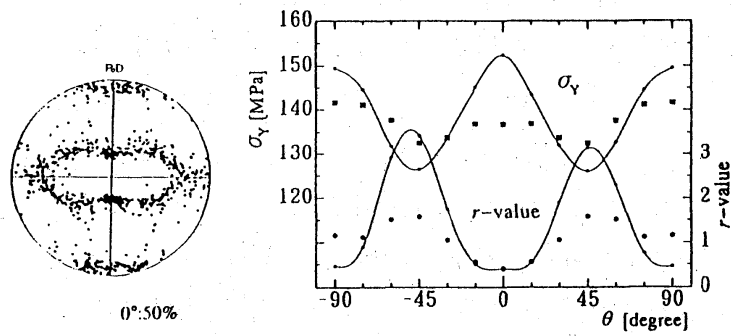

図 7 アルミニウム圧延板の異方性発達の予測

て数学的回転則と呼ばれている.

さて以上の格子回転則を用いてアルミニウム圧延板の 異方性の進展を計算してみる。as-received 材の極点図 （図 4）を基に多結晶モデルの初期結晶方位を定める。次 に数值的に $50 \%$ 圧延（平面ひずみ圧縮）を施し，極点図 の変化と $\mathrm{r}$ 值を求める。一例として $0^{\circ}$ 方向圧延の場合を 図 7 に示す。図 6 (a) の実験と比べると理論的予測はか なり強い異方性を与える。実験では異方性はある程度で 頭打ちなるが，計算ではどこまでも異方性が進展する。

\section{4 加 工 硬 化 則}

多結晶体の応力ひずみ曲線を計算するには，その中の 単結晶の加工硬化則が分かっていなければならない，多 結晶体内の単結晶は, 周囲の結晶粒と変位の連続を保ち ながら変形するために，一般に 5 個以上のすべり系が必 要である，すなわち多結晶体内の単結晶は常に多重す心゙ 
りによって変形していると考えなければならない．

一般に実験的に観察されるのは結晶粒全体の応力・ひ ずみなので，多重すべりの場合仮に活動すべり系の組み 合わせが分かっていたとしても，各すべり系ごとの $k$ と $\gamma$ を关机年れ独立に定めるには条件不足である。このた めに多重すべりに打ける加工硬化則を実験的に見い出す のは非常に難しい。

Hosford $^{11)}$ は単結晶の多重すべり変形を実現するため に単結晶の平面ひずみ圧縮試験を行い, 式 (5) の等方硬 化則が第一近似として正しいことを実証した。したがっ て焼鈍状態からの比例負荷応力ひずみ曲線の予測には Taylor の等方硬化則が有効である.

しかし加工硬化曲線はひずみ履歴に依存する。すなわ ち Bauschinger 効果や Jackson and Basinski ${ }^{12)}$ の潜在 硬化などである. 以下吕れぞれの現象毎にモデル化を試 みる。

\section{$4 \cdot 1$ バウシンガー効果}

一般にバウシンガー効果は, 粒界などに堆積した転位 からの逆応力で説明されることが多い（長範囲応力場説）. これが連続体塑性論の移動硬化則の物理的根拠となって いる. しかし Hasegawa ら ${ }^{13)}$ の電顕観察によれば予ひず み時に転位の七儿構造が形成され，逆応力負荷によって セル構造が消滅し, さらに逆方向の変形が進むと逆符号 のセル構造が再成される。この場合仮に逆応力が存在し たとしても, 七ル構造と共に消滅するはずで, 逆応力が 逆負荷を永久に助けるとは考えにくい．

長範囲応力場説によれば加工硬化は活動すべり系で最 も大きくなるはずであるが，実際は潜在硬化で見られる ように，活動していないすべり系の硬化の方がむしろ大 きい。このため加工硬化の説明としては林立転位による

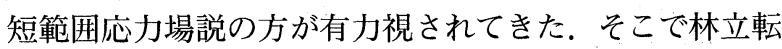
位に基づくバウシンガー効果の解釈を以下に試みる.

可動転位が林立転位を横切ってすべり面全体に広がる 時, 介在物とか林立転位が密集している部分は横切るこ とができず，オロワンループを残して通過する。変形が 進むにつれオロワンループが累積し，その中心部には強 い応力集中が起こる。この応力場が交差すべり系（二次 すべり系）の転位を引き寄せ，それと反応して応力集中 を緩和し，安定な転位網すなわちセル組織を形成する. 一方引き寄せられた二次転位は，一次すべり系の林立転 位として加工硬化の原因となる，予ひずみ時に蓄積され たオロワンループの中心部は, 林立転位と反応して逆負 荷に抢いても消滅しない。一方外側の未反応オロワンル ープは逆負荷によって一旦消滅する。ささらに逆負荷が続 くと逆符号のオロワンループが堆積し, 逆方向の応力集 中が発達して加工硬化が再開する.

高橋ら ${ }^{14)}$ はバウシンガー曲線には初め応力一定の遷移 領域が存在し，その後法負荷曲線と同じように加工硬化 することを見い出した。この遷移領域はセル構造の消 滅・再生に対応しているものと考えられる。この現象が 菌車のかみ合いに拈けるバックラッシに似ているので, “バックラッシモデル” ${ }^{15)}$ として以下に定式化する.
各すべり系において，加工硬化に有効なひずみ $\gamma_{a}$ を考 える. 図 8 に示すように負荷の初めは $\gamma_{a}$ はせん断ひずみ $\gamma$ と共に増加するが，点 A で応力が反転されると，非硬 化領域すなわちバックラッシ領域 $\gamma_{b}$ が出現する.

すべり系がこれまで経験した最大の加工硬化有効ひず みを $\dot{\gamma}_{n}=$ と打き， $\gamma_{b}$ は $\dot{\gamma}_{n}=$ の関数と仮定する. 実験結 果によれば $\gamma_{b}=\dot{\gamma}_{n}=$ と扔くことができる. バックラッ シ領域の中点を $\gamma_{c}$ と扰き, パラメータ $\xi=2\left(\gamma-\gamma_{c}\right) / \gamma_{b}$ を用いてバックラッシモデルを定式化する.

(1) $|\xi|=1$ (加工硬化状態) :

$$
\dot{\gamma}_{a}=|\dot{\gamma}| \quad \text { and } \gamma_{c}=\gamma-\gamma_{b} \operatorname{sign}(\tau) / 2
$$

(2) $|\xi|<1$ (バックラッシ領域) $: \gamma_{c}$ は一定.

$$
\left.\dot{\gamma}_{a}=|\dot{\gamma}|(\xi \operatorname{sign}(\tau)+\lambda) /(1+\lambda)\right)
$$

ただし

$$
\begin{aligned}
& \lambda=1 \text { for } \gamma_{a \mid \text { max }}<\gamma_{0} \\
& \lambda=0 \text { for } \gamma_{a \mid \max }>\gamma_{0} \text { where } \gamma_{0}=0.04
\end{aligned}
$$

以上のモデルによってアルミニゥム円管ねじり試験に よるバウシンガー曲線の計算 結果と実験の比較を図 9 に 示す.

\section{$4 \cdot 2$ 交差効果}

例えばねじり予ひずみ後引張り負荷を与えるような交 差負荷の場合，予ひずみ時に蓄積されたオロワンループ は拘束・未拘束を問わず全て交差すべり系に対して林立 転位として働く。このため新たに活動し始めた交差すべ り系の降伏応力は一時的に上昇する。 これが交差硬化ま たは潜在硬化である。しかし加工硬化が再開するために は，新たに活動し始めた交差すべり系のオロワンループ の蓄積が足りず，加工硬化の遅れが発生する。この交差 遅れを導入するために以下の “最大林立転位モデル” ${ }^{15)}$

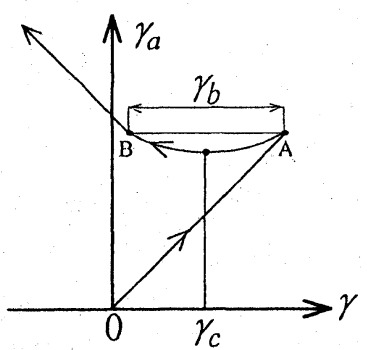

図 8 硬化過程ダイアグラム

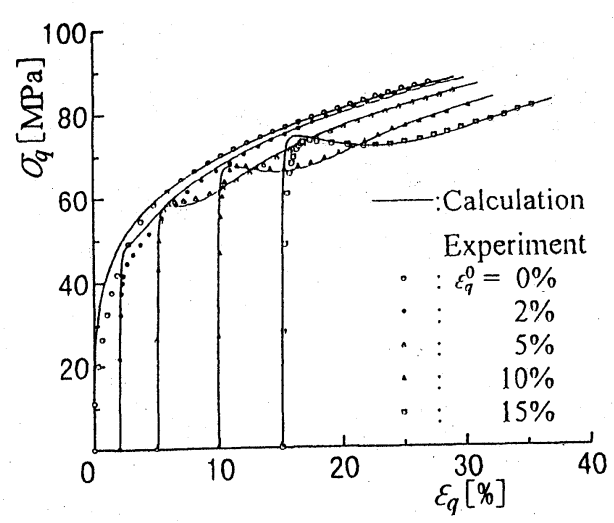

図 9 バウシンガー曲線のシミュレーション 
を提案する.

加工硬化有効ひずみ $\gamma_{a}$ の共面すべり系の和を $\overline{\gamma_{a}^{(\mathrm{p})}}$ と表 わす ( $p$ はすべり面を示す). 例えばすべり面 $p=1$ にと って $\gamma_{a}^{(2)}, \overline{\gamma_{a}^{(3)}}, \overline{\gamma_{a}^{(4)}}$ は林立転位密度を意味する。このうちの 最大值がすべり面 $p=1$ の変形抵抗を支配すると仮定する.

$$
k^{(p)}=H\left(\Gamma^{(p)}\right)
$$

ここで例えば $\Gamma^{(1)}$ は $\overline{\gamma_{a}^{(2)}}, \overline{\gamma_{a}^{(3)}}, \overline{\gamma_{a}^{(4)}}$, の最大值である.

このように仮定すると $\Gamma^{(p)}$ の值が更新されるまで $k^{(p)}$ は一定に保たれ, 交差遅れが表現できる. 以上のモデル を組み込んで，ねじり予ひずみ後の単純引張りによる交 差負荷曲線の計算結果と実験の比較を図 10 に示す.

\section{5 塑性加工解析}

実際の塑性加工解析に多結晶モデルを利用する際, 次 の二つの方法が考えられる.

（1）不均一な塑性変形の解析は従来の連続体塑性論 を用いる。その解析の基となる構成方程式のパラメータ 一の決定に多結晶モデルを利用する。

（2）塑性変形解析に直接多結晶モデルを適用する。こ の際有限要素解析における分割要素をそれぞれ多結晶体 とみなす考え方と, 一つの結晶粒とみなす考え方がある.

ここでは (2) の 1 要素 1 結晶粒の考え方をとる. 定式 化は数值材料試験の場合と同じであるが, 境界条件は問 題ごとに異なる.

\section{$5 \cdot 1$ 押出加工 ${ }^{16)}$}

丸棒の押出加工を考える. 軸対称変形を想定し, 横断 面の 1/6 扇形領域を計算領域とする. 中心付近と表面付 近で同じ形状の要素となるように, 三角柱要素を用いる. 要素分割を図 11 に示す. 要素数 720 , 節点数 588 であ る。断面減少率 $75 \%$ ，ダイス角 $45^{\circ}$ である。

素材をダイス内に徐々に押し込む非定常解析を行う。 しかし先端要素がダイス出口を出て十分離れれば, 定常 状態とみなすことができる。そこで変形の完了した先頭 要素一列を解析対象からはずし, その代わりに押し込み 側に新しい未変形要素一列を追加する。このようにして 変形終了後の要素から集合組織に関するデータを得る.

図 12 に素材中心部の集合組織の進展の様子を逆極点 図で示す.すなわち基準ステレオ三角形内に押出方向を 投影したものである。ダイス入口では等方的であった結 晶組織が, $<111>,<100>$ 方向の二重繊維組織に進展す

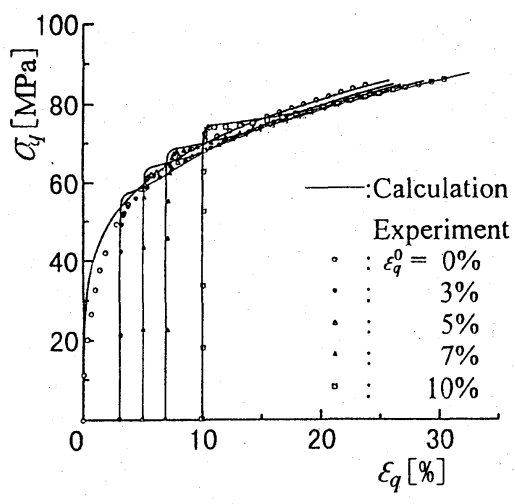

図 10 交差負荷曲線のシミュレーション

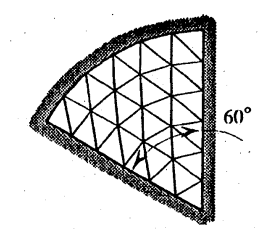

(a) 軕直们断面

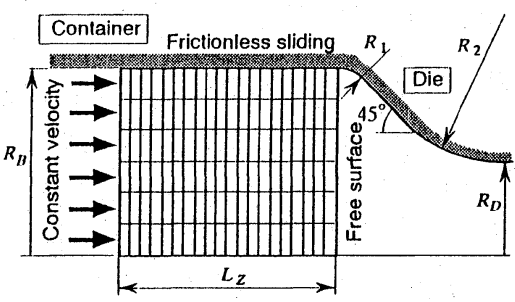

(b) 刺平行断面

図 11 押出加工解析の要素分割
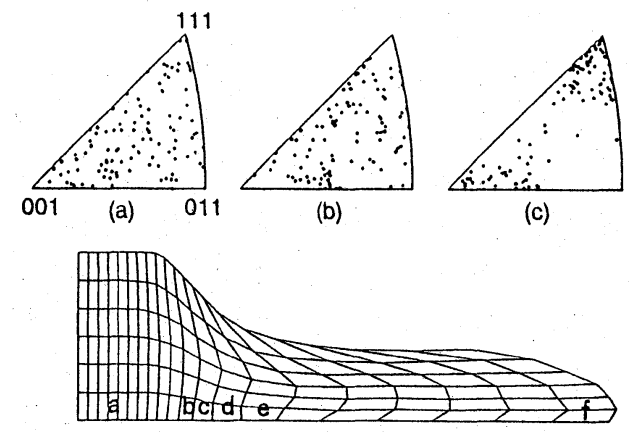

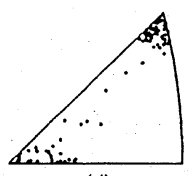

(d)

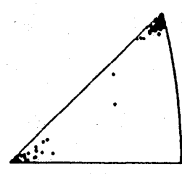

(e)

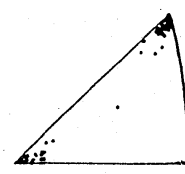

(f)
図 12 繊維組織の発達

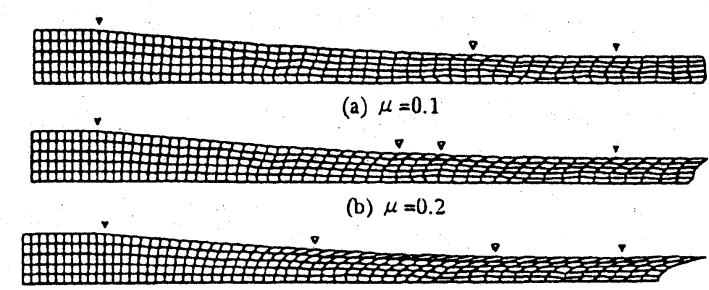

(c) $\mu=0.3$

図 13 圧延による変形の様子

る様子がよく分かる.

\section{$5 \cdot 2$ 圧延加工 ${ }^{17)}$}

計算例を図 13 に示す. $1 / 2$ 板厚方向に 5 分割，板幅 方向に 5 分割, ロール方向に 55 分割とし，要素数 1375 である，押出加工の場合と同様に，変形の終了した要素 列を削除し，未変形要素列を追加する操作を行う，FCC 金属とし降伏応力は一定とする. 初期結晶方位は乱数で 与える。圧下率 $50 \%$ である。

摩擦係数が大きくなるほど, 中心層と表面層の変形の 不均一が激しい，中央二つの三角印で挟まれた部分が無 すべり領域を表わす，摩擦係数が小さいとその領域が次 第にせまくなり， $\mu=0.1$ では一点となる．これが圧延の 
(a)
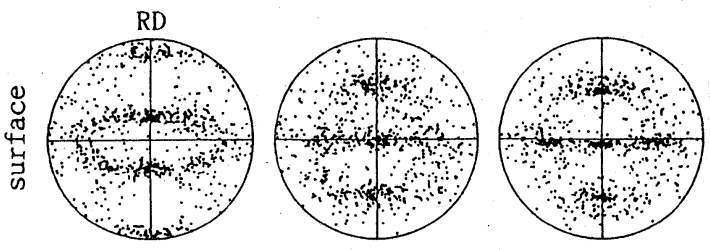

(b)
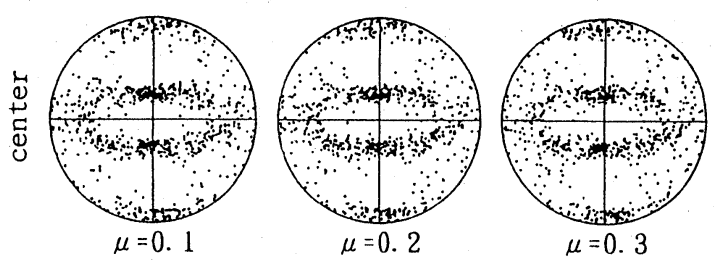

図 14 圧延による異方性

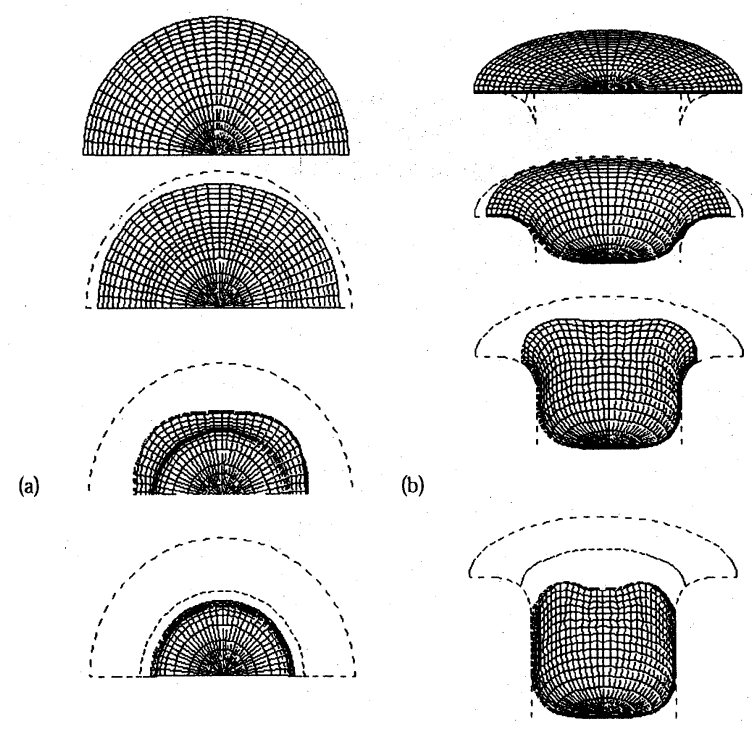

図 15 深絞り加工のシミュレーション

\section{初等解析における中立点である.}

次に圧延後の集合組織を（111）極点図として図 14 に 示す. (a) が表面層，(b) が中心層である. 中心が平面ひ ずみ圧縮, 表面がせん断による組織となっている.

\section{$5 \cdot 3$ 深絞り加工}

直径 $80 \sim 94 \mathrm{~mm}$, 板厚 $1 \mathrm{~mm}$ のアルミニウム円板を, 直径 $40 \mathrm{~mm}$ のポンチで深絞り加工する. 材料の加工硬 化特性は $\mathrm{n}$ 乗硬化則 で与える. ブランクの 半分を計算 対象とし, 円周方向に 32 分割, 板厚方向 3 分割, 半径 方向にはブランク径に応じて $17 \sim 23$ 分割する. 要素 数は全体 $1632 \sim 2208$ である. 面内分割一定のまま板厚 方向分割だけを増やすと，ポンチ荷重が上昇する，座標 は (x,y, z) デカルト座標を用い, 式 (17) による格子回転 を与える。

$50 \% 0^{\circ}$ 方向圧延板の極点図より結晶方位を定める．直 径 $80 \mathrm{~mm}$ の計算結果を図 15 に示す. (a) は平面図, (b) は側内面図である，次第に耳が形成される過程が示され ている.

$$
6 \text { あ。 とがき }
$$

以上結晶塑性論のこれまでの歩みと二, 三の応用例を を概観した．FCC 純金属に対しては打打よその骨格がで
きてきたように思われる。しかしまだまだ未完成であり 例えば次のような重要な問題が未解決である。

(1) 格子回転則

式 (17) による格子回転則は実際よりも強い異方性集合 組織を与える。この問題は以前から指摘され，原因が多 結晶モデルにあるのか，あるいは格子回転則にあるのか， 現在のところまだ分かっていない.

(2) 寸法効果

結晶粒の寸法が小さいほど，降伏応力が上がるという 有名な Hall-Petch の式がある。本解説の多結晶モデルで はこれを表現できない。

\section{（3） FCC 金属集合組織}

FCC 金属の圧延板集合組織には, 純銅型 $(\mathrm{Al}, \mathrm{Cu}, \mathrm{Ni})$ と黄銅型（7-3 黄銅，18-8 ステンレス鋼）の二種類存在 することが知られている。 これまでの多結晶モデルでは 純銅型の組織しか予知できない.

(4) BCC 金属

すべり方向は <111>で一定であるが，すべり面は $\{110\} ，\{112\} ，\{123\}$ と不定である。，それぞれの降伏せん 断応力が共通なのか異なるのか, また加工硬化はどうな るのかなど未解決の問題が山積している.

以上金属学的に知られている現象を力学的にモデル化 しようとすると，無数の困難な問題に遭遇する. 若き研 究者の参加を切に願うものである.

\section{参 考 文 献}

1) G. I. Taylor, J. Inst. Metals, 62, 307 (1938).

2) J. F. W. Bishop and R. Hill, Phil. Mag., 42, 414 and 1298 (1951).

3 ) J. D. Eshelby, Proc. Roy. Soc. Lond., A241, 376 (1957).

4) E. Kroner, Acta Metall., 9, 155 (1961).

5) B. Budiansky and T. T. Wu, Proc. 4th Congr. Appl. Mech., 2, 1175 (1962).

6) R. Hill, J. Mech. Phys. Solids, 13, 89 (1965).

7) J. W. Hutchinson, Proc. Roy. Soc. Lond., A319, 247 (1970).

8) T. H. Lin, Trans. ASME, J. Engng. Mater. Technol., 106, 290 (1984).

9) H. Takahashi, Int. J. Plasticity, 4, 231 (1988).

10) W. F. Hosford, Texture of Crystalline Solids, 2, 175(1977).

11) W. F. Hosford, Acta Metall., 14, 1085 (1966).

12) P. J. Jackson and Z. S. Basinski, Canadian J. Physics, 45, 707 (1967).

13) T. Hasegawa, T. Yakou and S. Karashima, Mater. Sci. Engng., 20, 267 (1975).

14) H. Takahashi and I. Shiono, Int. J. Plasticity, 7, 199(1991).

15) H. Takahashi, K. Fujiwara and T. Nakagawa, Int. J. Plasticity, 14, 489 (1998).

16）本橋 元, 影沢豊彦, 高橋 寛, 土田 信, 日本機械学会 論文集，A-61，353 (1995).

17）本橋 元，高橋 寞，土田 信，塑性と加工， 37, 201 (1996). 